\title{
地下水中に注入された空気の移動特性および 污染物質の濃度変化について
}

\author{
AIR MIGRATION AND CHANGE OF CONTAMINANT CONCENTRATION IN \\ GROUNDWATER INDUCED BY IN SITU AIR SPARGING
}

\author{
江種伸之 ${ }^{1}$ 平田健正 ${ }^{2} \cdot$ 福浦清 $^{3} \cdot$ 松下孝 $^{3}$ \\ Nobuyuki EGUSA, Tatemasa HIRATA, Kiyoshi FUKUURA and Takashi MATSUSHITA \\ ${ }^{1}$ 正会員 博士(工学) 和歌山大学助手 システム工学部環境システム学科（テ640-8510 和歌山市栄谷930) \\ ${ }^{2}$ 正会員 工学博士 和歌山大学教授 システム工学部環境システム学科 (テ640-8510 和歌山市栄谷930) \\ ${ }^{3}$ 前澤工業株式会社 土壤環境部（广332-8556 埼玉県川口市仲町5-11）
}

\begin{abstract}
The in situ air sparging technology, devised to facilitate contaminant volatilization with air injected into groundwater, was applied to a site contaminated with volatile organochlorines like tetrachloroethylene, carbon tetrachloride, chloroform etc. These substances were utilized to produce chemicals for many years. This paper examined air migration in groundwater, influence radius of sparging air and change of contaminant concentration due to air sparging technology. In this site, the mounding test was carried out to reveal detailed air migration in groundwater. As a result, the influence radius of sparging air was within $14 \mathrm{~m}$ and sparging air smoothly flowed in groundwater. And, in the in situ air sparging, the contaminant concentrations decreased at some observation wells in the domain of influence radius of sparging air. In particular, carbon tetrachloride, the Henry's constant of which was the highest among substances specified, decreased appreciably.
\end{abstract}

Key Words : in situ air sparging, mounding test, air migration, volatile substances

\section{1.はじめに}

トリクロロエチレンやテトラクロロエチレンな どの揮発性物質で污染された地下環境の修復技術 として, 土壤ガス吸引法やエアースパージング法 が考案され，晛地に適用されいつつめる ${ }^{12,2)}$. 土塨力 ス吸引法は不飽和帯に負圧をかけて(土㙵ガスの吸 引を行い)ガス態の物質を除去する．この方法では 地下水の揚水を同時に行う場合が多く(二重抽出 法 $)^{3)}$, 地下水中に溶解している物質も除去できる. ただし, 揚水した地下水は地上でばっ気処理を行 う必要があり，処理水の処分方法が問題である.

一方，エアースパージング法は地下水中に空気を 吹き込み，地下水の流れを攪乱することで溶解し ている物質を揮発させ，不飽和带でガスとして除 去する.この方法は二重抽出法と異なり, 污染さ れた地下水の処理が不要になる利点がある.

しかし，空気を吹き込むことで地下水の流れが
乱されるので，地下水や土裹ガス中の物質の回収 量に影響が生じる。また，污染物質を周辺へ拡散 させる危険性もある.すなわち，エアースパージ ング法を適用するためには，注入空気の移動特性 や空気の通過による地下水中の物質濃度変化を明 らかにしておくことが重要である。そこで本現場 実験では，トルエンやテトラクロロエチレンなど の揮発性物質で污染された地下水中に空気を注入 して, 地下水圧力, 土壤ガス圧力, 物質濃度を計 測し, 注入空気の移動特性, 影響範囲, および地 下水浄化効果を検討した.

\section{2. 現地状況}

本研究で対象としたのは化学工場で, 現在は跡 地になっている. 現地の地質状況は, 地表面から $-4 \mathrm{~m}$ までが表土とローム層，-5.75mまでが凝灰質粘 土層，-8mまでが砂まじりのシルト層，その下がシ 


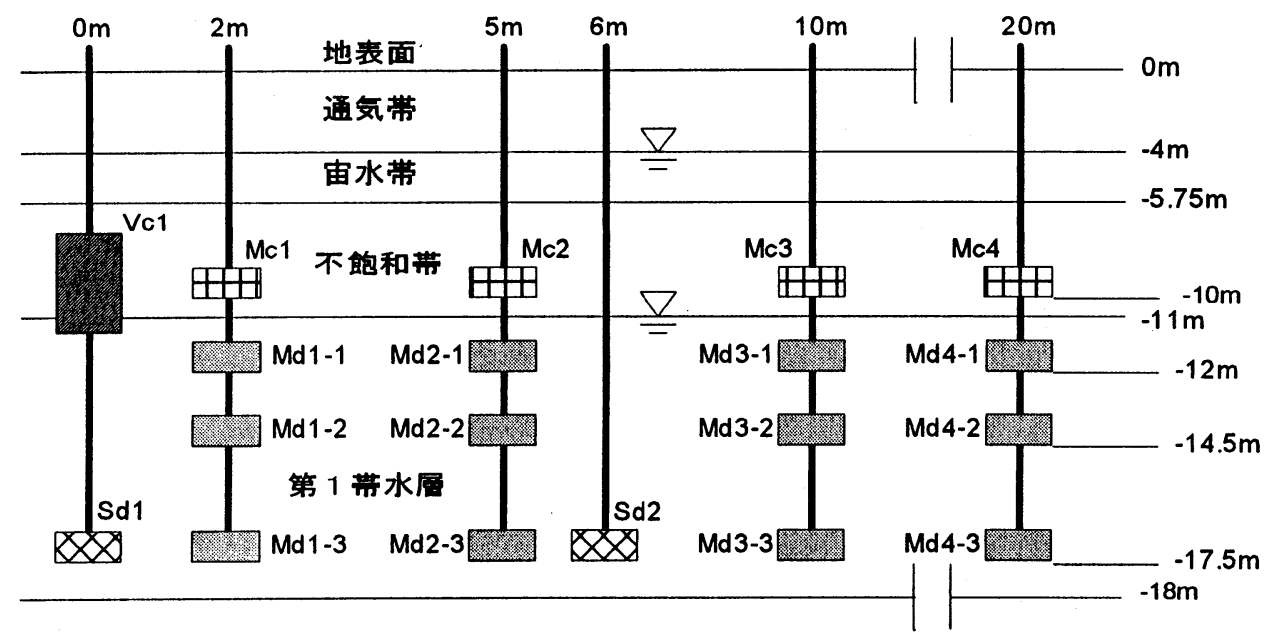

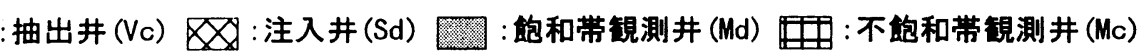

図-1 井戸配置図

ルト質細砂および砂層である，凝灰質粘土層の上 には-4mから-5.75mまで宙水帯が存在しており，そ の下に不飽和帯を挟んで-11m地点から第一帯水層 になっている．宙水帯と第一带水層に挟まれた不 飽和帯で行った透気試験結果から, 浄化対象地域 周辺の地質に異方性は見られなかった.

土壤中含有量試験によると，地下環境中にはト ルエン, テトラクロロエチレン, ジクロロメタン, 四塩化炭素, クロロホルムの計5物質が宙水带から 第一帯水層にかけて多く存在していた。 また, 地 下水中濃度を測定した結果，各物質は深さ12mの第 一帯水層中で高濃度を示した。 そこで, 今回の現 場実験では第一带水層の浄化を目的として空気の 注入を行った。

\section{3. 現場実験の概要}

今回の現場実験では，注入空気の影響範囲を測 定するためのマウンディング試験, および空気注 入井の位置を変えた 2 通りのエアースパージング法 の本運転を行った。図ー1に現地での土壤ガス抽出 井, 空気注入井, および観測井の配置図を示して いる. 今回は鉛直断面内での圧力や濃度変化が観 測できるように各井戸を配置した.

マウンディング試験は, 注入空気の流れを明ら かにして，その影響範囲および本運転時の污染の 拡散がないことを確認するために実施した。空気 注入井にはSd2を用い，本運転と同じ流量 $120 \mathrm{~L} / \mathrm{min}$ で1時間連続注入し, 飽和帯観測井で地下水圧力を 経時的に測定した。一方, 本運転は長期的な実験 を行って浄化効果を判断する前段階として, 注入 空気の移動特性や空気通過の影響による物質濃度
変化を明らかにするために実施した。そこで，運 転時間は短時間 (1ケース20時間)にし，土㙵ガス圧 力, 物質濃度などをできるだけ多く測定すること にした．3月25日から3月27日までは空気注入井と 土壤ガス抽出井が深度は異なるが同じ地点に位置 した運転で(RUN1)，25日11:00から26日7:00まで (RUN1-1) と26日 14:00から27日10:00まで (RUN12)の2回空気注入を行った. 一方，4月1日から4月 3 日までは注入井が抽出井から6m離れた場所に位置 した場合の運転で(RUN2)，1日11:00から2日7:00ま で (RUN2-1) と2日 14:00から3日10:00まで (RUN22)の 2 回空気注入を行った. 本運転でも注入・抽出 流量は一定として連続運転を行っている. 空気流 量は, 注入が $120 \mathrm{~L} / \mathrm{min}$, 抽出が $180 \mathrm{~L} / \mathrm{min}$ である. なお，抽出井では期間中は常時土壌ガス吸引運転 を行っている.

\section{4. 測定結果}

\section{(1) 地下水圧力}

図-2には，マウンディング試験によって得られ た各観測井での地下水圧力上昇幅の経時変化を示 している. 空気注入期間中 $(10: 00 〜 11: 00)$ はほぼ 全ての観測井で圧力の上昇が生じている。 また, 注入停止後には速やかに圧力が低下し始め, 停止 から5時間後 $(16: 00)$ には全ての地点でほぼ初期状 態に戻っている. 注入井に最も近いMd2-2では, 注 入期間中の圧力上昇が他の観測井と比べて大きい. また停止後 1 時間から 5 時間の間には圧力が初期状 態以下になっている.この現象はMd1-3,Md3-3な ど他の観測井でも見られるが, Md2-2で最も顕著で ある.一方，Md2-1ではMd2-2のように大きな圧力 


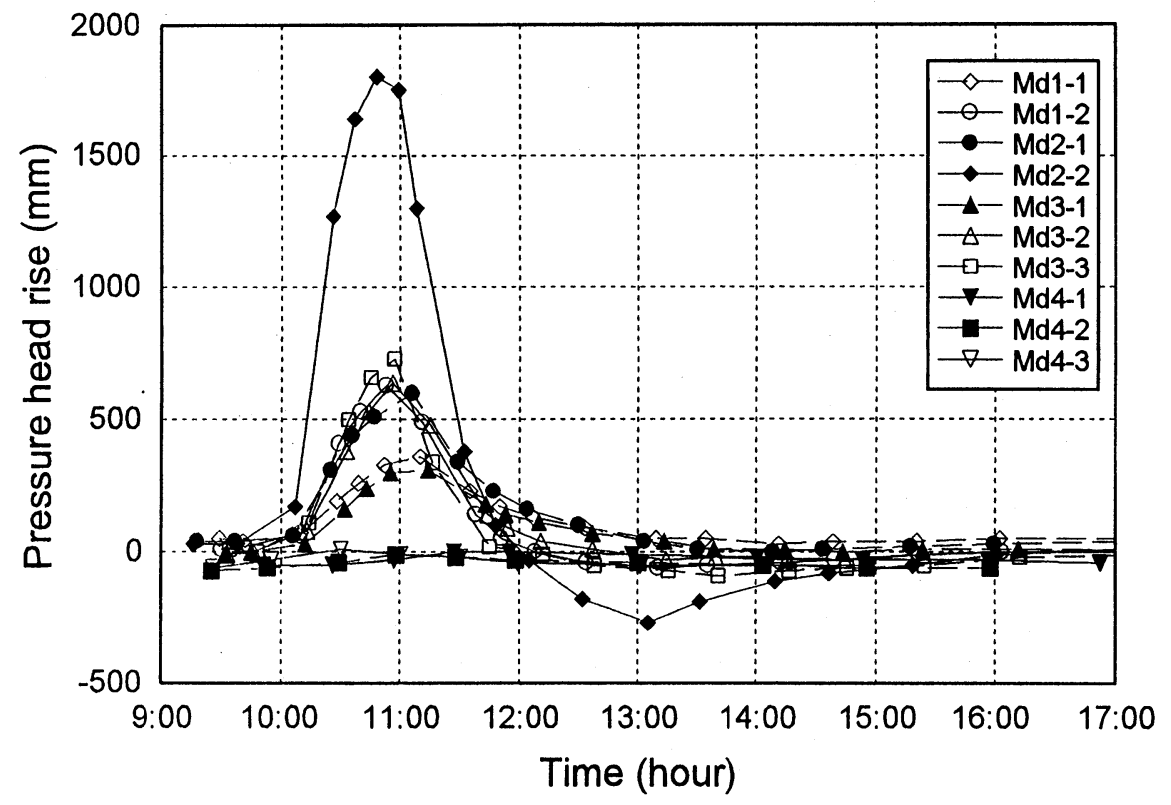

図-2 マウンディングに伴う地下水圧力の経時変化
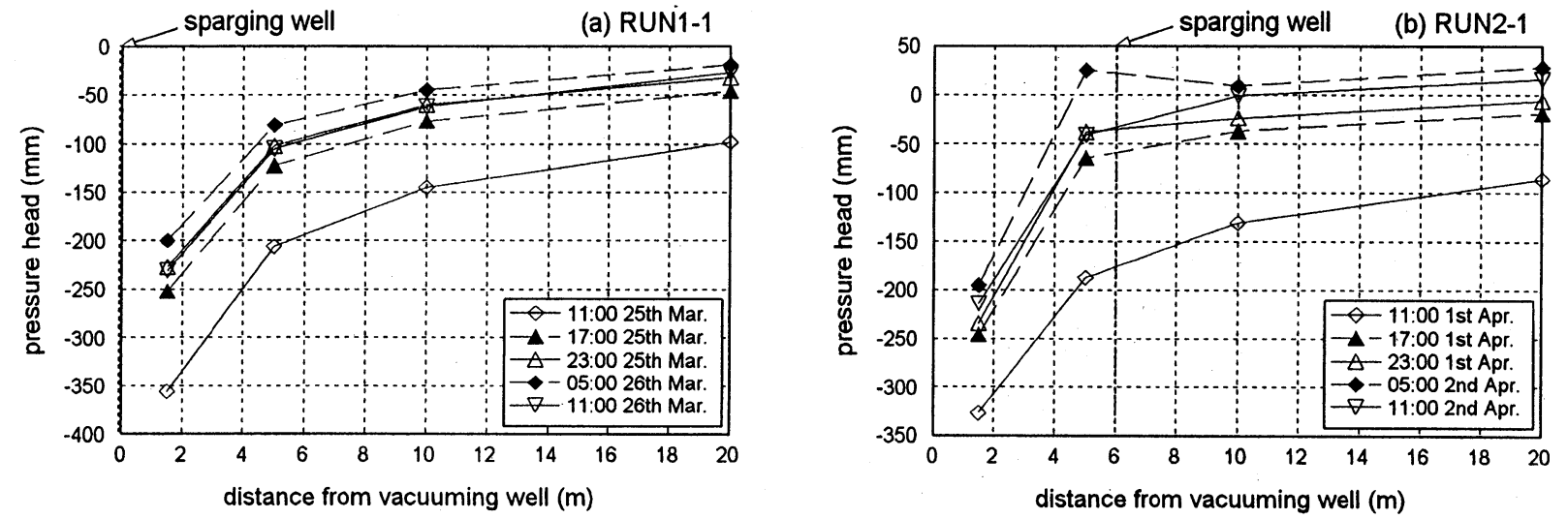

図-3 土壤ガス圧力および圧力勾配

の上昇はない，注入井から4m離れたMd3-1〜3では, 深い観測井ほど圧力上昇幅が大きくなっている. また, 注入井を挟んでMd3-1〜 3 とほぼ対称の位置 にあるMd1-1と2でも同程度の圧力上昇が生じてい る. 注入井から14m離れたMd4-1〜3では, わずかに 圧力の上昇が見られるが, 各深度毎の上昇幅の差 はほとんど無くなっている.

\section{(2) 土壤ガス圧力}

図-3 (a)-(b)には，RUN1-1およびRUN2-1運転中の 土壤ガス圧力および圧力勾配を抽出井の位置を原 点にとり描いている. 図-3(a)によると，ガス抽出 のみを行っている間は抽出井付近で土壤ガス圧力 の低下が生じる(3月25日11:00まで)。しかし, 抽 出の影響半径付近 (10m地点) ではあまり低下しない ため, 抽出井方向に圧力勾配がつくことになる。 空気注入を開始すると抽出井付近で他の地点より も大きな圧力の上昇が生じ, 抽出井を向いた圧力
勾配は小さくなる(3月25日17:00-26日5:00)。注入 停止後 (26日11:00)には抽出井付近の圧力が低下す るが，10m地点ではほとんど変化しないため, 圧力 勾配は再び大きくなる傾向にある.

図-3(b) では, 注入井が抽出井から6m離れた位置 にある.この場合も空気注入を開始することで注 入井付近 (6m地点) の圧力が上昇する (4月 1日 17:00 $\sim 4$ 月 2日5:00). しかし, 抽出井付近の圧力上昇は 小さいため, 結果として注入期間中は注入井から 抽出井を向いた圧力勾配が大きくなる. 注入停止 後 $(4$ 月 2 日 $11: 00)$ には注入井付近の圧力の低下が生 じ, 圧力勾配は再び小さくなっていく.

\section{(3) ガス濃度}

図-4には抽出井戸V $\mathrm{c} 1$ の抽出ガス濃度の経時変化 を示している. RUN1開始前とRUN2終了後の本運転 実施前後で, ある程度の濃度の低下が見られる. また, 運転中の抽出ガス濃度はいずれの物質も注 


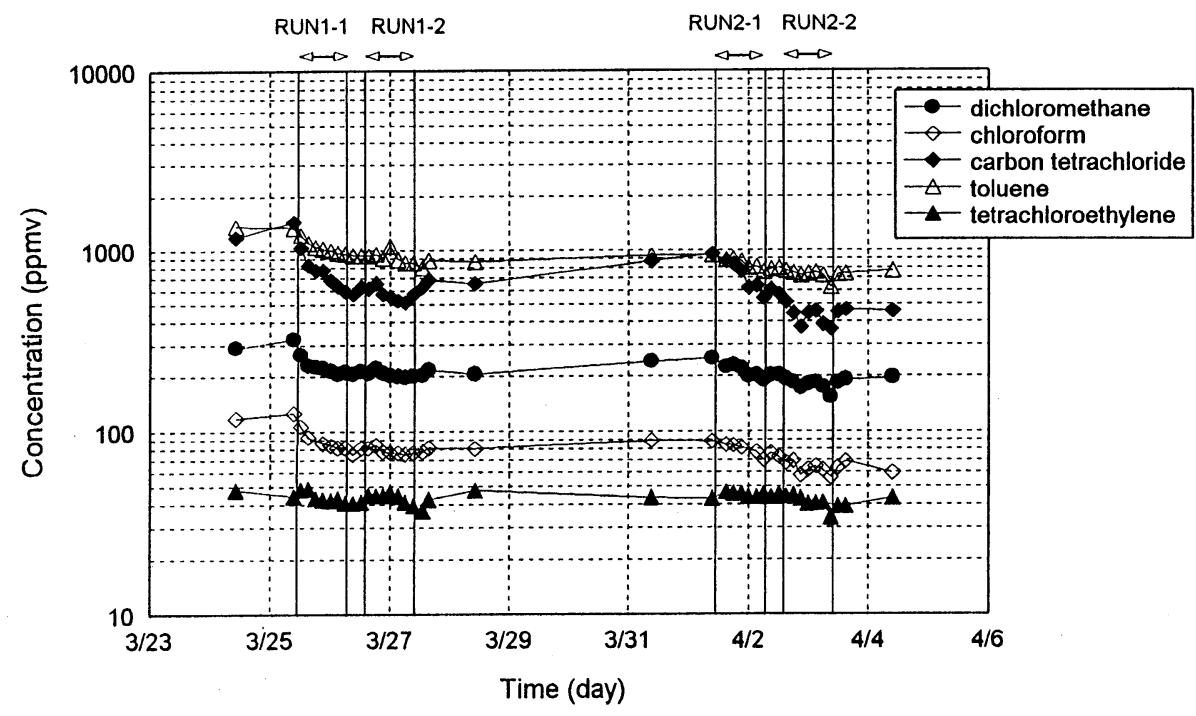

図-4 曲出ガス中の污染物質濃度
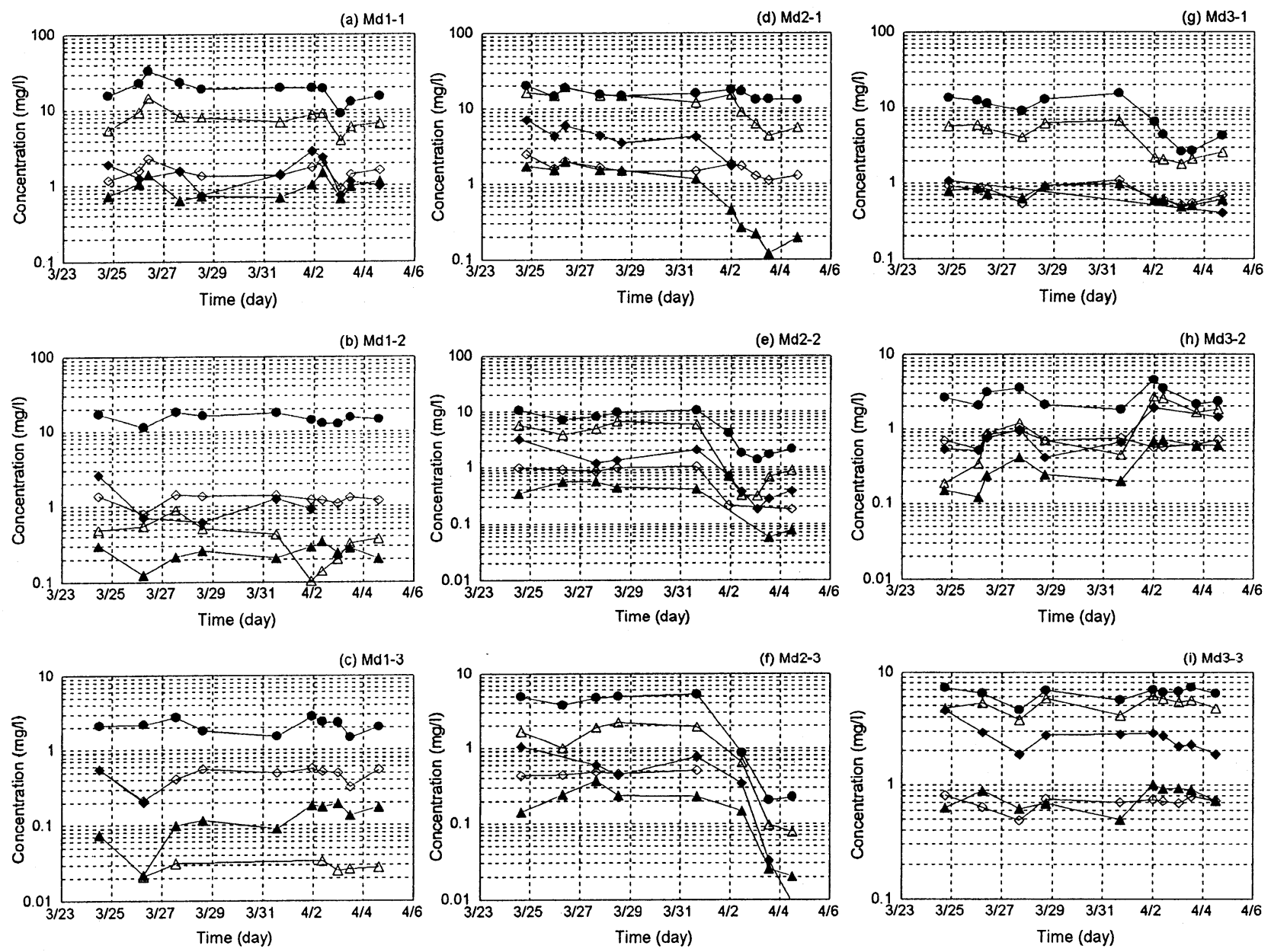

:dichloromethane, $\diamond$ :chloroform, $\diamond$ :carbon tetrachloride, $\Delta$ :toluene, $\boldsymbol{\Delta}$ :tetrachloroethylene

図-5 地下水中物質濃度

入開始とともに低下し，停止すると元のレベルに まで回復している．特にRUN1にその傾向が強く, RUN2では徐々に濃度が低下していく傾向にある. 一方, 周辺土袞ガス濃度に関しては, ガス抽出に よる濃度の低下や空気注入の影響などが見られな
かったので, ここでは割愛する.

\section{（4）地下水中濃度}

図-5 (a) - (i) に各物質の地下水中濃度の経時変化 を示している，RUN1運転中は特に大きく濃度が変 
化している様子は見られない，ただし，Md1-2,Md23およびMd3-3では四塩化炭素の浱度低下が他の物 質と比べて大きい。 また, 注入井に近いMd1-1では, RUN1-1運転中の四塩化炭素濃度が他の物質とは異 なり低下傾向にある。一方，RUN2運転中には注入 井に近いMd2-1〜3で各物質濃度が低下しており， またMd3-1でも低下傾向にある. 他の地点では全体 的に濃度の変動幅が大きくないので低下傾向にあ るとは言いにくいが，RUN2-1運転中の四塩化炭素 (Md1-1) やトルエン (Md1-2) の変動が他の物質と比 心゙て大きくなっている.

\section{5. 考察}

\section{(1) 注入空気の移動特性}

図-2のマウンディング試験によって得られた地 下水圧力の上昇から，ほとんどの観測井で注入空 気の通過の影響を見ることができる．また；注入 停止後にはどの観測井でも速やかに圧力が低下し 始めていることから，飽和帯中に空気溜りは生じ ておらず，注入空気がスムーズに流れていると考 えられる。ただし, 観測井によっては空気が直接 通過していなくても圧力の伝達により変化が生じ るので，Md4-1〜3のような圧力上昇の小さい場所 では直接空気が通過していない可能性もある.

一方, 空気注入による圧力上昇幅は観測井毎に異 なっている．空気注入開始前にはほとんど圧力差 がないので, 上昇幅の差はそのまま2地点間の動水 勾配になる。そこで, 空気注入停止時 (図-2中の 11:00)における飽和带観測井の地下水圧力上昇幅, および鉛直方向の動水勾配を図-6に示している. 地下水の流速はそれぞれの方向の動水勾配に透水 係数を乗じたもので表される，すなわち，鉛直方 向の動水勾配があればその地点では鉛直方向を向 いた地下水の流れがあり，ゼロならば流れがない ことになる，以上のことから，圧力上昇が生じ， かつ動水勾配が発生している地点では, 注入空気 の影響で地下水の流れが乱されている。言い換え れば，注入空気が通過している可能性が強い場所 である.

図-6から，Md2-2は注入井から水平距離で1mしか 離れていないため，算定できた動水勾配の中では 值が最大である。すなわち，空気通過量が非常に 多い地点と考えられる。注入井を挟んで対称な場 所に位置し, 水平距離で4m離れているMd1-2とMd32でも同程度の動水勾配が生じており, 空気通過の 影響による地下水の流れが見られる．ただし，動 水勾配がMd2-2の4分の1程度であることから，空気

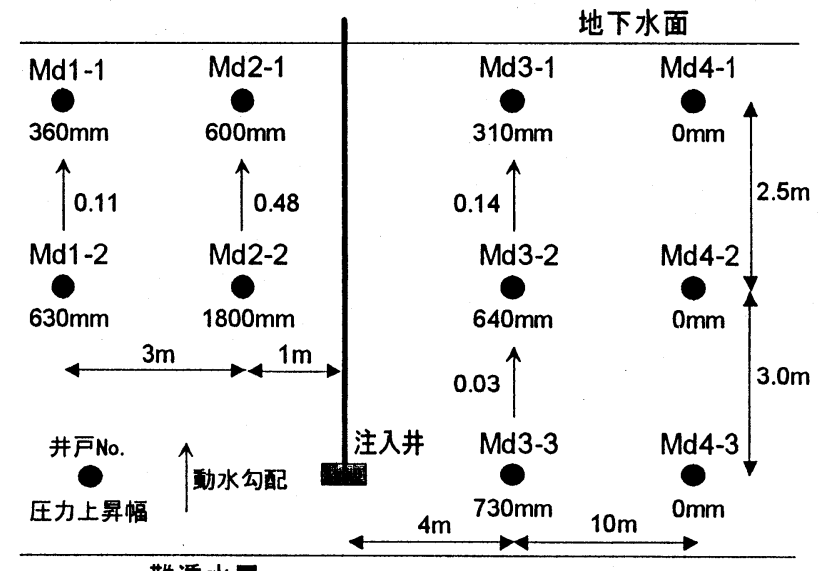

\section{難透水層}

図-6 能和帯観測井での圧カ上昇幅および動水勾配

通過量はMd2-2よりも少なくなっている. 一方, Md3-2の下方に位置するMd3-3では，距離的には Md3-2より注入井に近いが，鉛直方向の動水勾配が 4 分の1程度である.これは, 注入井と同じ深さで 水平方向に4m離れた地点 (Md3-3周辺) では, 注入空 気の通過があっても主な流路にはなっていないこ とを示している。すなわち，注入された空気は注 入井直上や斜め上方に向かって流れ, 主にMd2-2や Md1-2, Md3-2周辺を通過して不飽和帯に達している と思われる. したがって, 飽和帯中の物質濃度も これらの地点で変化が生じる可能性が強い, 注入 井から水平方向に14m離れたMd4-1〜3では，わずか ながら圧力が上昇しているが，上昇幅には差が見 られず，鉛直方向の地下水の流れがほとんど発生 していない.すなわち, 注入空気の通過の影響が ほとんどない場所である，このことから，本実験 の影響範囲は14m以内と考えられる。

\section{（2）土壌ガスの移動特性}

土袞ガス吸引によって不飽和土袞中のガス態の 物質を除去する場合, 抽出井における吸引風量が 除去できる範囲 (影響範囲)を決定する。この影響 範囲内では, 吸引によって生じる抽出井を向いた 移流フラックスが回収量に大きな影響を与える ${ }^{4)}$. すなわち, 土壌ガスの圧力勾配が重要となる. 前 章第2節で述べたように, 抽出のみを行っている場 合には抽出井方向に圧力勾配が生じるため, 抽出 井に向から土壌ガスの流れが発生し, 周辺のガス 態の物質が回収されている。

図-3 (a) では, 空気注入を開始することで抽出井 方向の圧力勾配が抽出だけを行っている場合より も小さくなっている.これは空気の注入によって 抽出井に向から土壌ガスの流れが小さくなること を意味している，したがって，带水層の異方性を 
考えないなら，RUN1運転中は全方向から抽出井に 向から土壤ガスの流れが小さくなり，周辺土壌ガ スの回収量が減る。そして, 抽出流量が一定の場 合には，周辺からの回収量が減った分だけ不飽和 帯中に出てきた注入空気が回収されることになる。 このことから，図-4においてRUN1運転中に注入を 開始すると抽出ガス濃度が低下している現象は, 注入空気中に揮発する物質濃度が周辺ガス濃度よ りも低いことを意味している。

一方図-3(b)では，空気注入による注入井付近の 土壤ガス圧力の上昇によって, 注入井から抽出井 を向いた圧力勾配が抽出だけの場合よりも大きく なる。このため, 注入井から抽出井に向かう土壤 ガスの流れが大きくなり，このライン上の土壌ガ ス回収量が増える、ただし，今回は注入井を1つし か設置していないので，土壤ガスの回収量が増え るのは抽出井と注入井を結んだライン上のみで, 他の方向からの回収量は増えない，また，注入空 気も注入井の位置する方向からしか回収されない ので，RUN2運転時の注入空気の回収量は全方向か ら回収されるRUN1よりも少なくなる。したがって， RUN2では注入が始まってもRUN1ほど急激に抽出ガ ス濃度が低下していない(図-4).

\section{（3）地下水中濃度の変化}

図-5(a)-(i)によると, RUN1では全体的に濃度の 変動が小さいが, Md1-1, 2, Md2-3およびMd3-3では 四塩化炭素漶度に低下の傾向が見られた。四塩化 炭素は対象となった5物質のうちで一番ヘンリー定 数が大きく，最も揮発し易い物質である．すなわ ち, これらの地点における四塩化炭素濃度の低下 は注入空気中八の揮発によって生じた可能性が強 い。ただし，Md3-3は注入井と同じ樑さで10m離れ た場所にあり，第1項の注入空気の移動特性から判 断すると, 注入空気の通過の影響でない可能性も ある。したがって，詳細については今回得られた 注入空気の移動特性, 影響範囲を考慮しながら, 今後の長期運転によって判断する必要がある.

一方, RUN2運転中は注入井に近いMd2-1〜3では 各物質濃度が低下するが，運転停止後には回復し ている。これは, 注入空気の流路付近でのみ濃度 の低下が生じており, 今回程度の運転時間では周 辺地下水の濃度を低下させるほど空気注入の影響 が大きくなかったことを意味している，すなわち， 短期間の空気注入の影響で濃度が低下した地点で は, 運転停止後には周辺地下水の影響を受けて直 ちに濃度が回復する、マウンディング試験から得 られた注入空気の流路から判断すると, Md3-3
Md1-3では注入空気の影響が小さいので濃度が低下 していない。一方，注入空気が流れていると考え られるMd1-1，2，Md3-1および2の中では，Md3-1で 各物質濃度が低下しており，また，RUN2-1運転中 の四塩化炭素 (Md1-1) とトルエン $(M d 1-2)$ の濃度低 下の傾向が他の物質と比べて大きい. Md1-1に関し ては，RUN1の場合と同じようにヘンリー定数の一 番大きな四塩化炭素だけが空気注入の影響を強く 受けたためと考えられる.Md1-2のトルエンに関し ては今回の観測のみでは特に原因はつかめなかっ た。これは，今回程度の注入時間では濃度を十分 低下させるほどの空気流量がなかったためであり， 今後長期運転を続けることで注入空気の影響を見 ていく必要がある.

\section{6. おわりに}

本研究は, 地下水中に空気を注入した場合の注 入空気の移動特性, 影響範囲, および注入空気に よる污染物質の濃度変化の様子を明らかにするた めに現地実験を実施し，短時間の集中観測を行っ た. その結果, マウンディング試験から注入空気 の飽和帯中での挙動がおおよそ明らかになった。 空気注入による地下水中の濃度変化は, 今回の本 実験が短時間だったために明瞭には表れていない が, 注入空気の通過の影響がある地点のいくつか で低下の傾向が見られた。また，注入井と抽出井 の位置がガス回収量に大きく影響するため, 井戸 の配置の仕方が浄化効率を上げるためには重要で あることも明らかになった。

今後は, 空気注入による污染地下水修復を長期 間継続するとともに，この資料を基に数值シミュ レーションによる注入空気の移動特性や物質濃度 変化などの詳細な現象解析を行って, 浄化効果を 確認していく予定である.

\section{参考文献}

1)笠水上光博ほか: エアースパージング・揚水システム の効果, 第4回地下水・土䇎污染とその防止対策に関す る研究集会講演集, pp.339-342, 1995.

2)笠水上光博・山内仁・岡田滋 : エアースパージング • 揚水システムの効果その 2 , 第5回地下水・土壌污染と その防止対策に関する研究集会講演集, pp.373-378, 1997.

3) 平田健正ほか：土壌ガス吸引と地下水揚水を併用した 地下環境污染の修復, 環境工学研究論文集, Vol. 33, pp. 47-55, 1996.

4) 江種伸之・神野健二：土㙵ガス吸引時における有機塩 素化合物ガスの挙動について, 地下水学会誌, Vo1.37, No. 4, pp. 245-254, 1995. 